\title{
Characterization of suicidal intent and family risk factors in adolescents
}

\begin{abstract}
Introduction: The adolescent suicidal intent in the county of Villa Clara and their incidence in the municipality of Santa Clara Face and due to it arises it the demand of assuming a detailed characterization to prevent statement I lash.
\end{abstract}

Objective: To characterize of suicidal intent and family risk factors in adolescents.

Methods: A study of traverse descriptive type was used. The study population conformed to for 20 adolescents. The main variables were: age, sex, used methods, family operation and educational method that it was obtained starting from an applied survey and the contained data in the clinical histories of the patients.

Results: Belonged together with the groups of intent risks in which it prevailed the feminine sex and the age of 15 year-old incidence. It was corroborated that the suicidal intents in the adolescence were associated with inadequate in the family communication or distorted, isolated family, hostile mother-child relationship or father-son.

Conclusions: The lack of warmth in family relationships, rejection, lack of interest, reaction of parental irritation and lack of sufficient physical comfort, appear as the most frequently associated factors to suicidal behavior.

Keywords: adolescents, suicide, family, risk factors, prevention, family relationships, rejection, lack of interest, physical comfort, old incidence
Volume 3 Issue I - 2019

Jesús Cuéllar Álvarez

Master in Psycho Pedagogic, Policlinic “José Ramón León Acosta, Cuba

Correspondence: Jesús Cuéllar Álvarez, Master in Psycho Pedagogic, Policlinic “José Ramón León Acosta”, Santa Clara, Cuba,Email jesusca@infomed.sı.cu

Received: December 10, 2018 | Published: January 03, 2019

\section{Introduction}

Adolescence is framed by exploration and precisely motivating behaviors of suicidal ideas due to the existence of psychosocial risks. Prevention is actions aimed at the eradication, elimination and minimization of the impact of the disease and disability; it includes social, political, economic and therapeutic measures. ${ }^{1}$ Suicidal behaviors in adolescents are defined as "the concern, intent or act that intentionally seeks to cause harm to one or death."However, although it is necessary to consider periodizations about adolescence, it is worth noting that this age and youth are primarily psychological ages, since it is assumed that development is a process that does not occur automatically or fatally determined by the maturation of the organism, but it has first of all a social historical determination. ${ }^{2}$ According to the World Health Organization (WHO) ${ }^{3}$ when analyzing the suicide widely, it states that every 40 seconds a person commits suicide in the world, which brings to an annual million the number of those who decide to end their lives, a epidemic that increasingly extends to young people.

At present the phenomenon of suicidal attempt generates a social and individual problem from the inappropriate behavior of adolescents which motivated to carry out the present investigation belonging to the teaching polyclinic "José Ramón León Acosta of Santa Clara, Villa Clara, Cuba with its general objective to characterize of suicidal intent and family risk factors in adolescents.

\section{Methods}

A cross-sectional descriptive study belonging to the Polyclinic "José Ramón León Acosta" of Santa Clara was carried out in the period from April 2017 to October 2018. The universe consisted of 20 adolescents who met the following criteria to participate in the study.

\section{Inclusion approaches}

I. All adolescents with previous suicide intent.

II. That they reside in the health area belonging to a health area and are dispensed.

\section{Exclusion approaches}

Adolescents whose legal guardians do not give consent to participate in the investigation.

\section{Exit criteria}

That they abandoned the investigation.

\section{Methods of the theoretical level}

I. Synthetic analytical: It made possible the interpretation of each one of the studied texts, to conform the criterion assumed in the epigraphs and paragraphs, as well as to particularize in the data obtained in the surveys to integrate them and to establish the corresponding generalizations.

II. Inductive-deductive: It facilitated going from the particular to the general in each of the analyzes carried out in the theoretical study and in the processing of the obtained information.

III. Generalization: It allowed the establishment of the regularities that were revealed in the study carried out.

\section{Methods of the empiric level}

I. Open interview: It made it possible to provide information on the adolescents.

II. Clinical histories: Contribute to identify risk factors of the suicidal intent and family functioning in the adolescents. 


\section{Collection of information}

In order to carry out the research, the documentary review and individual clinical histories were used as techniques in order to obtain extended information. The following variables were used from the data obtained: age, sex and risk factors in the suicidal intent and family functioning.

\section{Statistic analysis}

The data obtained were stored in a computerized database and processed through the SPSS system. V. 15 for Windows. Statistical techniques were used according to the descriptive design of the work. It was used as absolute frequency (number) and relative (percentages) as summary measures. For the quantitative variables, the mean and the standard deviation were determined as a measure of central tendency and dispersion. The association between qualitative variables rested on the test of independence of variables, based on the chi-squared distribution. A significance level of 0.05 was used.

\section{Results}

As can be seen in Table 1, the female sex predominated with $77.7 \%$ of the participants and the age group of 15-19 years with $55.5 \%$ of them. This corresponds to the groups of risk of suicide attempt in which female sex predominates and ages over 15 years. Regarding family functioning, $52.7 \%$ of the family nuclei obtained the dysfunctional classification followed by the severely dysfunctional with $19.4 \%$ Table 2 . The most frequently observed educational method was the inconsistent one in $19(52.7 \%)$ of the family nuclei, while the permissiveness and rigidity were presented in $10(27.7 \%)$ and $5(13.8 \%)$ of them, respectively. As shown in Table 3, the highest incidence in adolescents is the risk factors generated from the social and family context due to triggering causes such as depression, low tolerance to frustrations, lack of affective communication of their parents and the rejection in adolescent groups.

Table I Distribution of adolescents according to age and sex

\begin{tabular}{llllllll}
\hline & Sex & & \multicolumn{3}{c}{ Total } \\
\hline Groups of ages & Female & \multicolumn{3}{c}{ Male } & & & \\
& No. & $\%$ & No. & $\%$ & No. & $\%$ \\
\hline I0-14 years & 14 & 38,8 & 2 & 5,5 & 16 & 44,4 \\
I5-19 years & 14 & 38,8 & 6 & 16,6 & 20 & 55,5 \\
Total & 28 & 77,7 & 8 & 22,2 & 36 & 100 \\
\hline
\end{tabular}

Source: Open interview

Table 2 Distribution of adolescents according to family functioning

\begin{tabular}{lllllllllll}
\hline Educational method & \multicolumn{1}{l}{ Inconsistent } & \multicolumn{2}{l}{ Permissiveness } & \multicolumn{2}{l}{ Rigidity } & \multicolumn{3}{l}{ Overprotection } \\
\hline Family functioning & No & $\%$ & No & $\%$ & No & $\%$ & No & $\%$ & No & $\%$ \\
\hline Functional & I & 2,77 & 0 & 0 & 0 & 0 & 2 & 5,55 & 3 & 8,3 \\
Moderately functional & 0 & 0 & 2 & 5,55 & 5 & 13,8 & 0 & 0 & 7 & 19,4 \\
Dysfunctional & II & 30,5 & 8 & 22,2 & 0 & 0 & 0 & 0 & 19 & 52,7 \\
Severely dysfunctional & 7 & 9,4 & 0 & 0 & 0 & 0 & 0 & 0 & 7 & 19,4 \\
Total & 19 & 52,7 & 10 & 27,7 & 5 & 13,8 & 2 & 5,55 & 36 & 100 \\
\hline
\end{tabular}

Fisher's exact statistic $=31,596 \quad p=0,000$

Table 3 Distribution of adolescents according to risk of suicide

\begin{tabular}{lll}
\hline & Total \\
Risk of suicide & No & $\%$ \\
\hline Family & 18 & 50 \\
Personal & 9 & 25 \\
School children & 6 & 16,6 \\
Social & 3 & 100 \\
\hline
\end{tabular}

Source: Clinical histories

\section{Discussions}

The behavior of suicide rates in some European countries are identified as incidences for Spain 8.3 per 100,000 inhabitants; France 6.1 for every 100,000. In Latin America, the region reveals that 1.9 per 100,000 Peruvian men end their lives, compared to 10.8 per 100,000 Chilean men. Colombia is not out of these figures, it is estimated that five people take their lives every day in the country. In 2011 , this phenomenon represented $7 \%$ of violent deaths in Colombia, with 1889 cases and a rate of 4 suicides per 100,000 inhabitants. ${ }^{4}$
Researchers such as Aguilar Hernández I, Perera Milian LS, Esquivel Rodríguez D, Barreto García ME, ${ }^{5}$ point out that in cities such as Bogotá, an increase in suicide rates in 2016 showed an increase of $18 \%$ compared to previous years. In the reviewed bibliography ${ }^{6}$ it was found that those who are more likely to risk suicidal attempts are those adolescents exposed to the socio-cultural pathway, among which is male alcohol consumption. This approach corresponds to the results obtained in the survey conducted with the group where they said they drink toxic substances when they go out for a walk, at parties and sharing tastes and preferences with friends. As a motivation, they refer that they do it "... by group contagion", "... to be approved by the group", "... to comply with rules of friends", “... to seek group pleasure", "... to avoid family conflicts". Usually, it is reported that the age of onset of consumption begins in early adolescence, however, there are other authors who place it after 14 years. ${ }^{7}$ To eradicate such risks as a scourge that threatens the lives of adolescents, it is necessary to adopt preventive measures to reduce their impact. ${ }^{9}$ That is why dysfunctional relationships that are generated in a family environment, could be considered as a predictor of suicide attempt and this could increase the risk that adolescents generate clinical symptoms. ${ }^{10,11}$

Usually, it is reported that the age of onset of drug use begins in early adolescence, ${ }^{12}$ however, there are other authors such as Paterno 
$\mathrm{CA}^{13}$ and Righetti $\mathrm{J}^{14}$ that place it after 14 years, constituting an open door to the attempt suicide. The most used method for the suicide attempt was the intake of drugs specifically psychopharmaceuticals, the easy access to these substances in the home and the predominance of the female sex could somehow explain the preference, where similar findings are found in other research contexts in countries like Chile, Peru, Colombia. ${ }^{15,16}$ Worldwide, men present more lethal methods than women, and according to research in China and India there are exceptions: China with the ingestion of pesticides and India with suicide a lo bonzo. ${ }^{17-19}$

\section{Conclusion}

Suicidal intention is a frequent behavior in adolescents, predominantly female. The suicidal intention in adolescence must be of great concern and justifies the focus on the attention of researchers, health care professionals, responsible for making community policy decisions that encompass the family and society in general. As a conclusion of the study, there is a high rate of lack of family communication under the evidence of conflicts between adolescents and their parents, with the influence of group imitation as well as personal and social problems of psychological development in adolescence.

\section{Acknowledgments}

None.

\section{Conflicts of interest}

The author declares there is no conflict of interest.

\section{References}

1. Quintero Fleites EJ, de la Mella Quintero SF, Gómez López L. La promoción de la salud y su vínculo con la prevención primaria. Medicentro Electrónica. 2017;21(2):11.

2. Domínguez L. Psicología del Desarrollo, Adolescencia y Juventud. La Habana: Universidad de La Habana. 2013;2.

3. Según la Organización Mundial de la Salud, una persona se suicida cada 40 segundos. 2013.

4. Pérez Barrero SA. ¿Cómo evitar el suicidio en adolescentes? Psicología Online. Prevención del suicidio. 2013.
5. Armendáriz-García NA, Almanza-López JB, de Jesús Alonso-Castillo MT. La historia familiar y la conducta de consumo de alcohol como factor sociocultural en el adolescente. Rev Perspectiva de Enfermería. 2015;15(2):219-27.

6. González Henríquez 1, Berger Vila K. Consumo de tabaco en adolescentes: factores de riesgo y factores protectores. 2014.

7. Quintero Fleites EJ, de la Mella Quintero SF, Gómez López L. La promoción de la salud y su vínculo con la prevención primaria. Medicentro Electrónica. 2017;21(2):11.

8. Rodríguez García FD, Sanchiz Ruiz ML, BisquerraAlzina R. Consumo de alcohol en la adolescencia: Consideraciones médicas y orientaciones educativas. Salud Ment. 2014;37(3):11.

9. Adolescencia. ¿Qué es la adolescencia?. 2013.

10. Ugarte Díaz RM. La familia como factores de riesgo, protección y resiliencia en la prevención del abuso de drogas en adolescentes. Capítulo 5. 2014.

11. González Henríquez 1, Berger Vila K. Consumo de tabaco en adolescentes: factores de riesgo y factores protectores. 2014.

12. Paterno CA. Factores de riesgo coronario en la adolescencia. Estudio FRICELA. 2014.

13. Righetti J. Factores de riesgo en la niñez y adolescencia (Fundamentos de las recomendaciones FAC '99 en prevención cardiovascular). 2014.

14. Von Dessauer B, Ortiz P, Hinostroza T, et al. Intento de Suicidio Vía Ingesta de Fármacos en Niños. Rev Chil Pediatr. 2011;82(1).

15. Zoila Pacheco A. Algunos factores de riesgo del intento de suicidio en adolescentes Hospital Guillermo Almenara I. Rev peruana pediatría. 2010;63(2).

16. Pérez-Olmos I, Ibáñez-Pinilla M, Reyes-Figueroa JC, et al. Factores Asociados al Intento Suicida e Ideación Suicida Persistente en un Centro de Atención Primaria. Bogotá, 2006-2008. Rev Salud pública. 2009;10(3).

17. Organización Mundial de la Salud. 2012.

18. Suicidio y comportamiento suicida. 2013

19. Silva N, Valdivia B. Comparative study of two scales of depression in relating to suicide attempt in no consultant adolecents. Rev chil neuropsiquiatría Chile. 2013;15(1). 